\title{
Comprehensive Site Chronology and Ancient Mitochondrial DNA Analysis from Verteba Cave - a Trypillian Culture Site of Eneolithic Ukraine
}

\author{
Alexey G. Nikitin ${ }^{a^{*}}$, Mykhailo P. Sokhatskyb, Mykola M. Kovaliukhc, Mykhailo Y. Videiko ${ }^{\mathrm{d}}$ \\ ${ }^{a}$ Biology Department, Grand Valley State University, Allendale, MI 49401, USA \\ ${ }^{b}$ Borschiv Regional Museum, Ministry of Culture and Arts of Ukraine, Shevchenka St. 9, Borschiv, Ukraine \\ Institute of Environmental Radiogeochemistry, National Academy of Sciences of Ukraine, Palladin Av. 34a, Kyiv, Ukraine \\ ${ }^{d}$ Institute of Archeology, National Academy of Sciences of Ukraine, Geroiv Stalingrada St. 12, Kyiv, Ukraine
}

\section{ARTICLE INFO}

\section{Article history:}

Received 23 November 2010

Accepted 20 January 2011

\section{Keywords:}

Trypillian culture complex (TC)

Eneolithic

Ukraine

radiocarbon dating

mitochondrial DNA (mtDNA)

\begin{abstract}
This manuscript presents a study of a ritual site of the Trypillian culture complex (TC) in western Ukraine where material artefacts are found side-by-side with human and animal remains. The organic content in pottery sherds made it possible to carbon date the ceramics found with bone remains, thus allowing a reference point for carbon dating bone collagen. This allowed us to develop a comprehensive chronology of the usage of the cave. Mitochondrial DNA (mtDNA) extracted from human remains shed additional light on the history of the site's occupation by early agrarians on the territory of Ukraine.
\end{abstract}

\section{Introduction}

Farming in Europe spread from western Anatolia after 7000 BC (Bellwood 2005). The European Neolithic initially developed in Greece, from where it expanded northward into the Balkans, and westward along the Mediterranean coast (Bellwood 2005). After 6000 BC Neolithic cultures of the Danube basin, such as Starčevo-Körös-Kriş and the Linear Pottery culture (Linearbandkeramik or LBK) began to appear east of the Carpathian Mountains (Kotova 2003). On the foundations laid by these and other Neolithic groups a new archaeological culture began to form in the pre-Carpathian region around $5400 \mathrm{BC}$. This culture became known as Precucuteni, and later as Cucuteni in Romania and Moldova, and Trypillia A (formally spelled "Trypolie" or "Tripolye") followed by Trypillia B and C, in Ukraine.

The Trypillian cultural complex (TC) existed from 5400 to $2700 \mathrm{BC}$ on a vast area extending from the Carpathian piedmont, east to the Dnipro River, and south to the shores of the Black Sea (Videiko 2004). As an archaeological culture TC was discovered in 1896 by V. Khvoika near the village

"Corresponding author. E-mail: nikitin@gvsu.edu
Trypillia, Ukraine (Khvoika 1901). TC is characterised by advanced agriculture, developed metallurgy, pottery-making, sophisticated architecture and social organisation, including the first proto-cities on European soil (Videiko 2004). TC occupies a prominent place in Eastern European archaeology but still remains largely unknown to the Western science.

The new TC chronology identifies the following brackets for each TC phase: AII-III-3 from 5400-4300 BC, BI from 4300-4100 BC, BII from 4100-3600 BC, CI from 3600-3200 $\mathrm{BC}$, and CII from 3400-2750 BC (Videiko 2004). More than 40 local archaeological groups are recognized within the TC complex, with region- and group-specific variations in the styles of pottery and plastics, in many cases influenced by contemporaneous neighbouring cultures (Videiko 2004).

At the material culture level TC is known for a variety of painted pottery as well as anthropomorphic and zoomorphic clay figurines (Childe 1923, Kandyba 1937, Zbenovich 1996, Videiko 2004). While the material culture of TC has been well studied and documented, human remains are scarce. In fact, they are virtually non-existent until the CII phase, when burials of TC begin to appear on a regular basis (Dergatschov 1991, Dergatschov, Manzura 1991). This creates a gap in our understanding of the biological origins of TC and in their cultural traditions, such as rituals for the dead. 


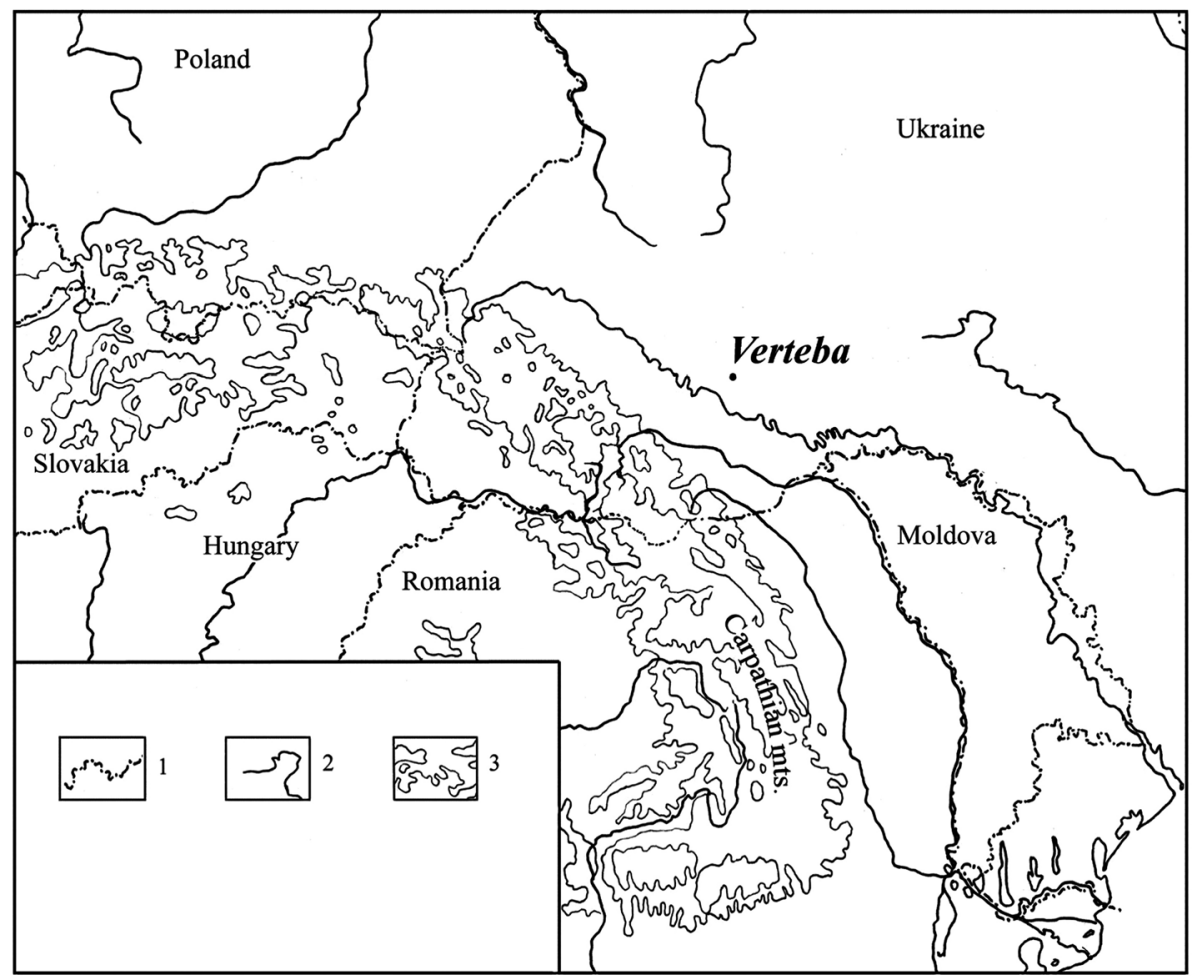

Figure 1. Map of the Podillya region with adjacent areas of Ukraine and neighbouring countries showing the approximate location of Verteba Cave. Legend: 1, country borders; 2 , rivers; 3 , mountain ranges.

One TC site that produced an extended record of human remains is Verteba, an 8,555-meter long gypsum cave in the Podillya region of Ukraine, on the bank of the Seret River (Figure 1). Verteba is located $1.5 \mathrm{~km}$ from the town of Bilche Zolote in the Ternopil Province of Ukraine (48.47 latitude and 25.53 longitude). Verteba is part of a large group of gypsum caves in the area, none of which (except for Verteba) have been utilised by humans until modern times. Verteba occupies a unique place in TC culture and in regional prehistory.

Verteba Cave and its Trypillian artefacts became known to the archaeological community since its accidental discovery in 1822 (Rook, Trela 2001). Archaeological excavations at the cave started in 1876 at which time human remains were unearthed from a $0.45 \mathrm{~m}$ layer of topsoil covering the entire floor surface of the cave (Krushelnytska, Bandrivsky 1998). A systematic archaeological excavation started in the cave in 1890 and lasted three years. During the next round of archaeological examination in the Verteba Cave from 1898 to 1904 , a flattened bone plate in the shape of a bovid head with an outline of a woman figure etched on the surface was found near the cave entrance (Figure 2A). Today this plate along with over 300 clay vessels 900 and boxes filled with over 35 thousand pieces of ceramics, 120 anthropomorphic and zoomorphic figurines, and other artefacts found during early discoveries at the cave are housed at the Museum of Archaeology in Krakow, Poland (Kadrow et al. 2003).

Excavations at the cave carried on throughout the $20^{\text {th }}$ century. In 1914 additional finds of human remains were made along the cave walls (Stojanowski 1948). Since 1996 the cave has been studied on a regular basis by the archaeological team from the Borschiv Regional Museum. To date the team excavated a total of $64 \mathrm{~m}^{2}$ of the cave area uncovering a wealth of artefacts.
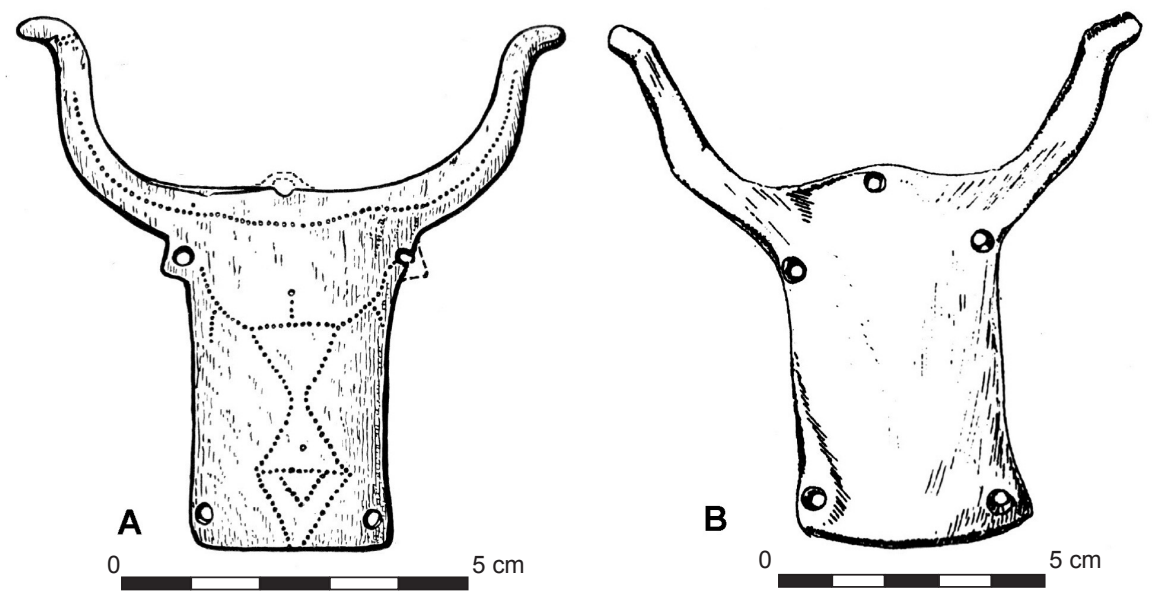

Figure 2. Two bovid-head shaped bone plates found at Verteba Cave. A, plate found by V. Demetrikevich (Krakow Archeological Museum, Poland). B, plate found by $\mathrm{M}$. Sokhatsky (Borschiv Regional Museum, Ukraine). 


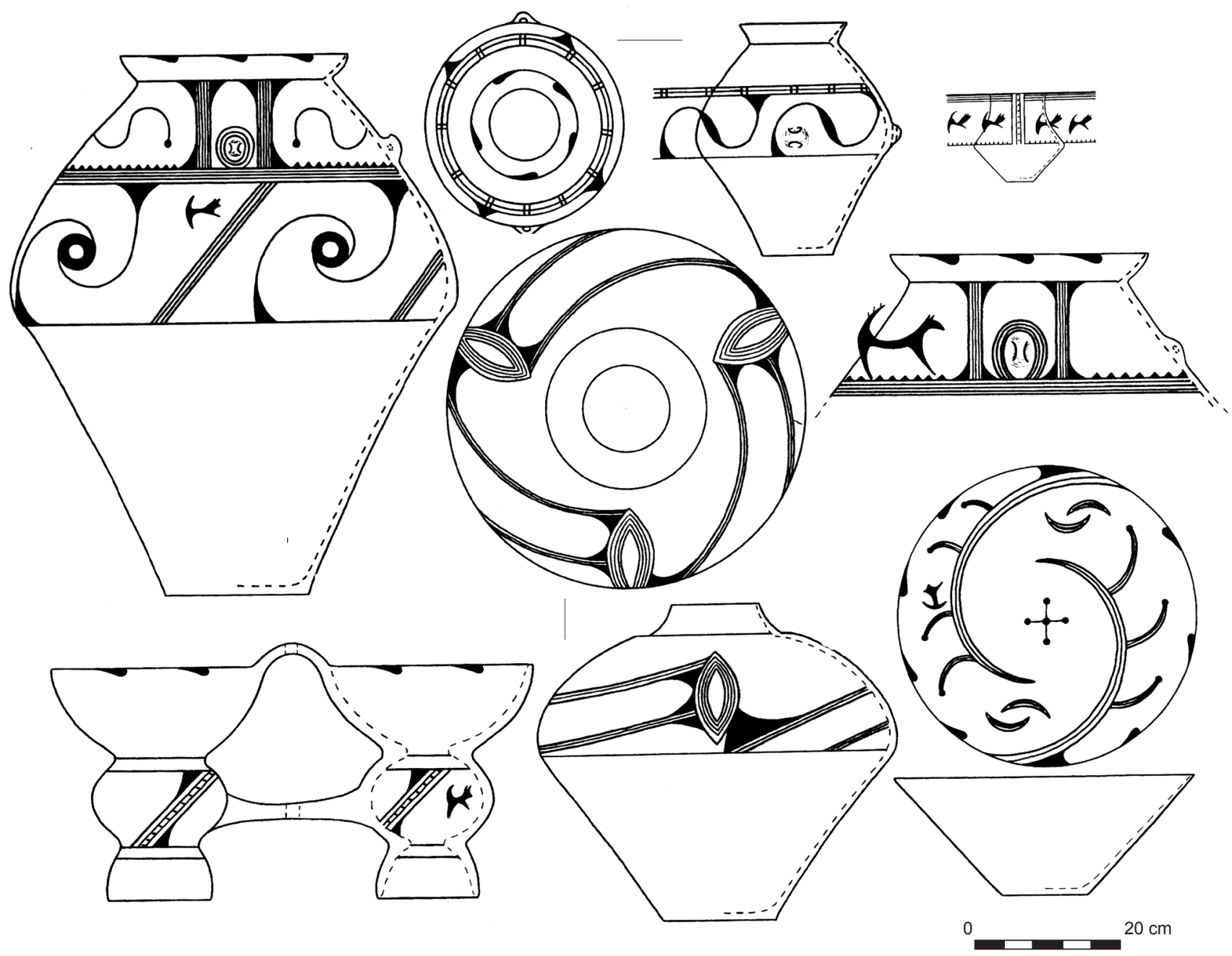

Figure 3. Schypynetska group ceramics of the Trypillian Culture Complex (after T. Tkachuk).

Based on the analysis of the ceramics and plastics typology three cultural horizons have been identified and matched to the corresponding archaeological layers in Verteba Cave (Kadrow et al. 2003). These horizons belong to the BII, CI and CII periods of the Trypillian chronology and represent three local groups of TC: Schypynetska, Koshylovetska, and Kasperivska.

The Schypynetska (SHY) group (BII/CI, 3900-3450 BC) was originally categorised with the Central group of the Painted Pottery culture of south-eastern Europe (Childe 1923), along with the Bilche Zolote group (to which Verteba belongs) and the Cucuteni group (Childe 1923). The pottery of the Central group typologically belongs to the Eneolithic stratum of the Cucuteni site (Cucuteni II) and is characterised by grooved pottery with spiral ornamentation (Childe 1923, Kandyba 1937). The SHY pottery was painted with deep red, black or brown and creamy white colours on a red wash or whitish primer (Childe 1923). The same colours are found at the Bilche-Verteba sites. The pottery shapes are represented by conical dishes, deep bowls, bulging and bi-conical urns, and binocular-shaped vessels. The first cultural horizon of Verteba belongs to this group (Figures 3, 6C).
The Koshylovetska (KO) group (CII, 3450-3100 BC) was originally placed in the North-Western group of the Painted Pottery culture sites by Childe (1923). The toponymic site of Koshylivtsi (3200-3000 BC) belongs to phase II of the KO group. KO pottery was covered by a white or pink primer on which black or red paint was applied. Exquisitely made and colourfully adorned anthropomorphic and zoomorphic figurines are typical for this group. Female figurines outnumber male figurines by 9 to 1 and are more than twice the size (Videiko 2004). The second cultural horizon of Verteba belongs to this group (Figures 4, 6E).

The Kasperivska (KA) group, also known as GorodskoKasperovsky or Gordyneshtsky type (CII, 3125-2775 BC) is known by its incised and mostly colourless pottery. Most of the known burials of the Trypillian culture (over 20 sites to date) are associated with this group (Videiko 2004). These are secondary burials under house floors, cremations, earthen graves and kurgans, accompanied by broken or intact pottery and miscellaneous inclusions. The third cultural horizon of Verteba belongs to this group (Figures 5, 6F).

The only radiocarbon dates available prior to the current report that support the pottery and plastics-based chronology 


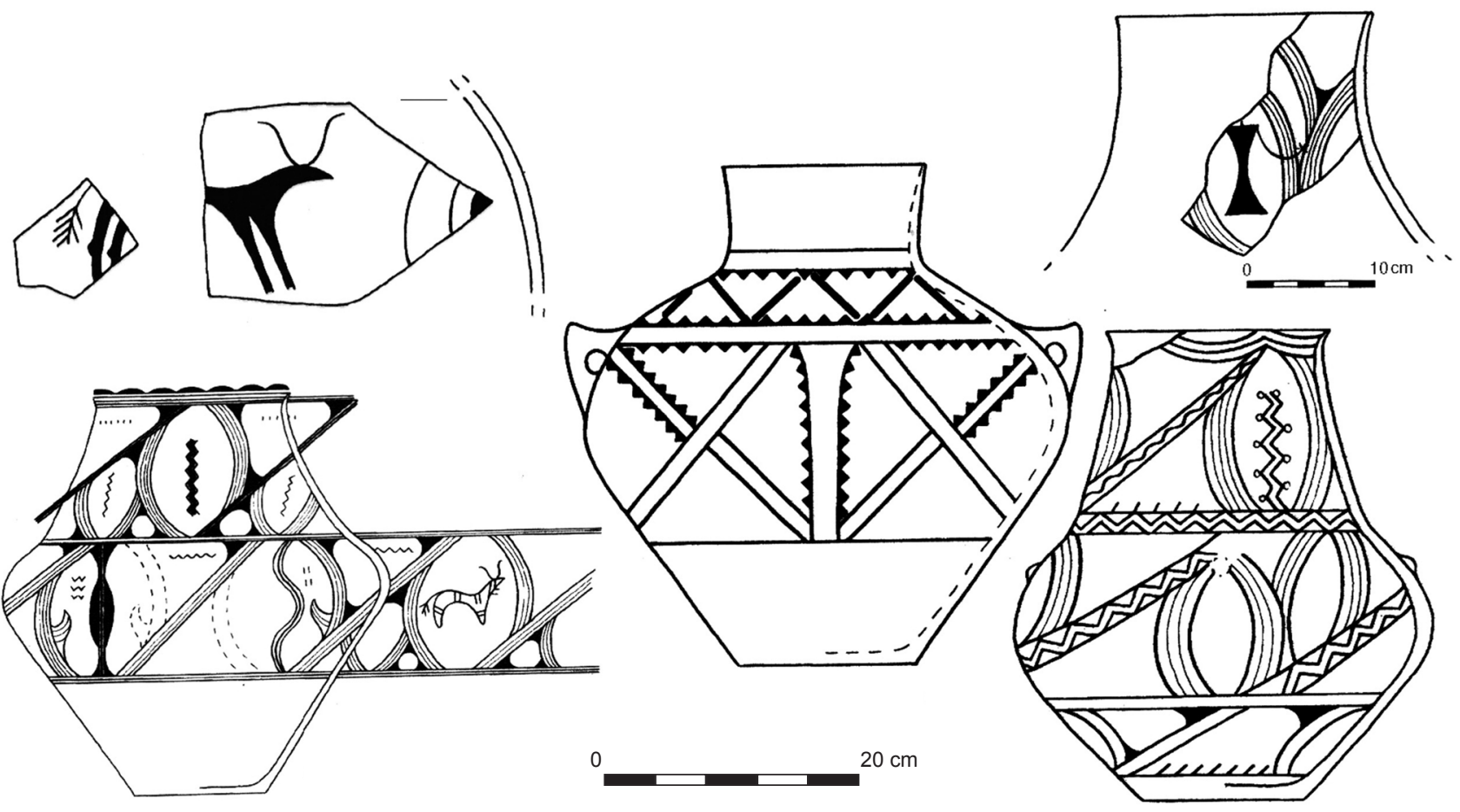

Figure 4. Koshylovetska group ceramics of the Trypillian Culture Complex (after T. Tkachuk).

of the TC occupation of Verteba were three single dates obtained on osteological material representing the three cultural layers of the cave (Kadrow et al. 2003). These dated the first layer to $4940 \pm 80 \mathrm{BP}$ (3951-3538 cal BC), the second layer to $4800 \pm 80 \mathrm{BP}(3758-3371 \mathrm{cal} \mathrm{BC})$, and the third layer to $4280 \pm 80 \mathrm{BP}$ (3265-2620 cal BC) (Kadrow et al. 2003). The goals of the current study were to produce a comprehensive series of radiocarbon dates for Verteba, using pottery, human and animal remains, as well as to extract and analyse ancient DNA (aDNA) from human remains. While the detailed genetic analysis has been submitted for publication elsewhere a discussion of the place of TC in the
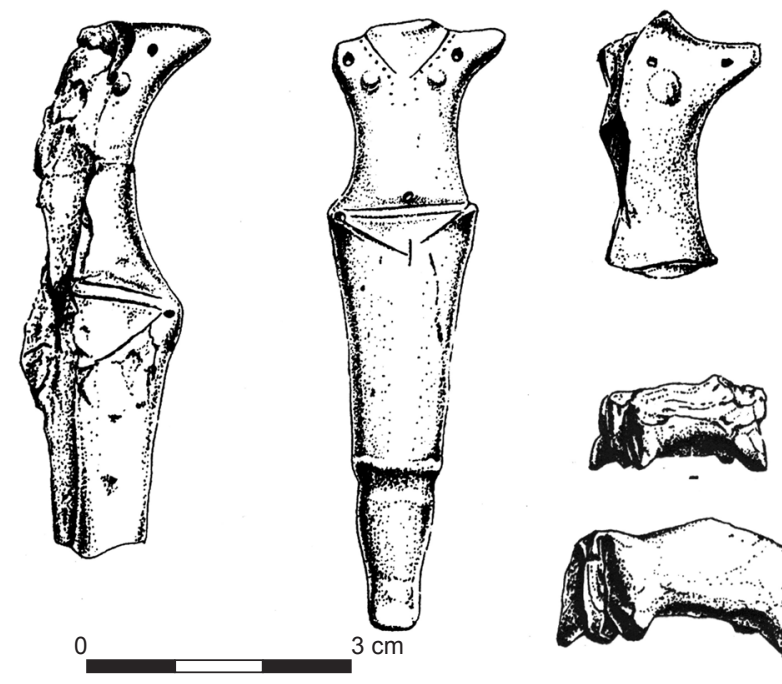

Figure 5. Representative plastics from the Kasperivska group of the Trypillian Culture Complex. population history of Neolithic Europe based on the results of the genetic analysis is presented in this report.

\section{Materials and Methods}

\subsection{Sample collection, radiocarbon dating and pottery typology}

Material for radiocarbon dating presented in this report was collected during the 2005 and 2007 excavations (sites are shown on Figure 7). Samples for radiocarbon dating consisted of human and animal bone, pottery sherds, charcoal and matrix. The majority of samples came from the outer portion of site \#7, which has been excavated by the Borschiv Regional Museum since 1996. The excavated surface covers an area of $14 \mathrm{~m}^{2}$ and is particularly rich in artefacts. Pottery typology was done prior to radiocarbon dating and without the knowledge of the specific location site. On sherds with no characteristic ornamentation, such as kitchen pottery, typology could not be done (marked N/A in Table 1).

Radiocarbon dating was performed at the Kyiv Radiocarbon Laboratory. Ukrainian Neolithic ceramics, particularly Trypillian ceramics, has a high organic carbon content (up to $4 \%$ by volume) and a low concentration of carbonates. This feature allows the direct dating of TC pottery sherds.

\subsection{Ancient DNA analysis}

Ancient mitochondrial DNA (mtDNA) was extracted from seven bone specimens collected at each of the seven sites presented in Figure 7. Samples from which DNA has been extracted are noted in Table 1. Sterile conditions were 


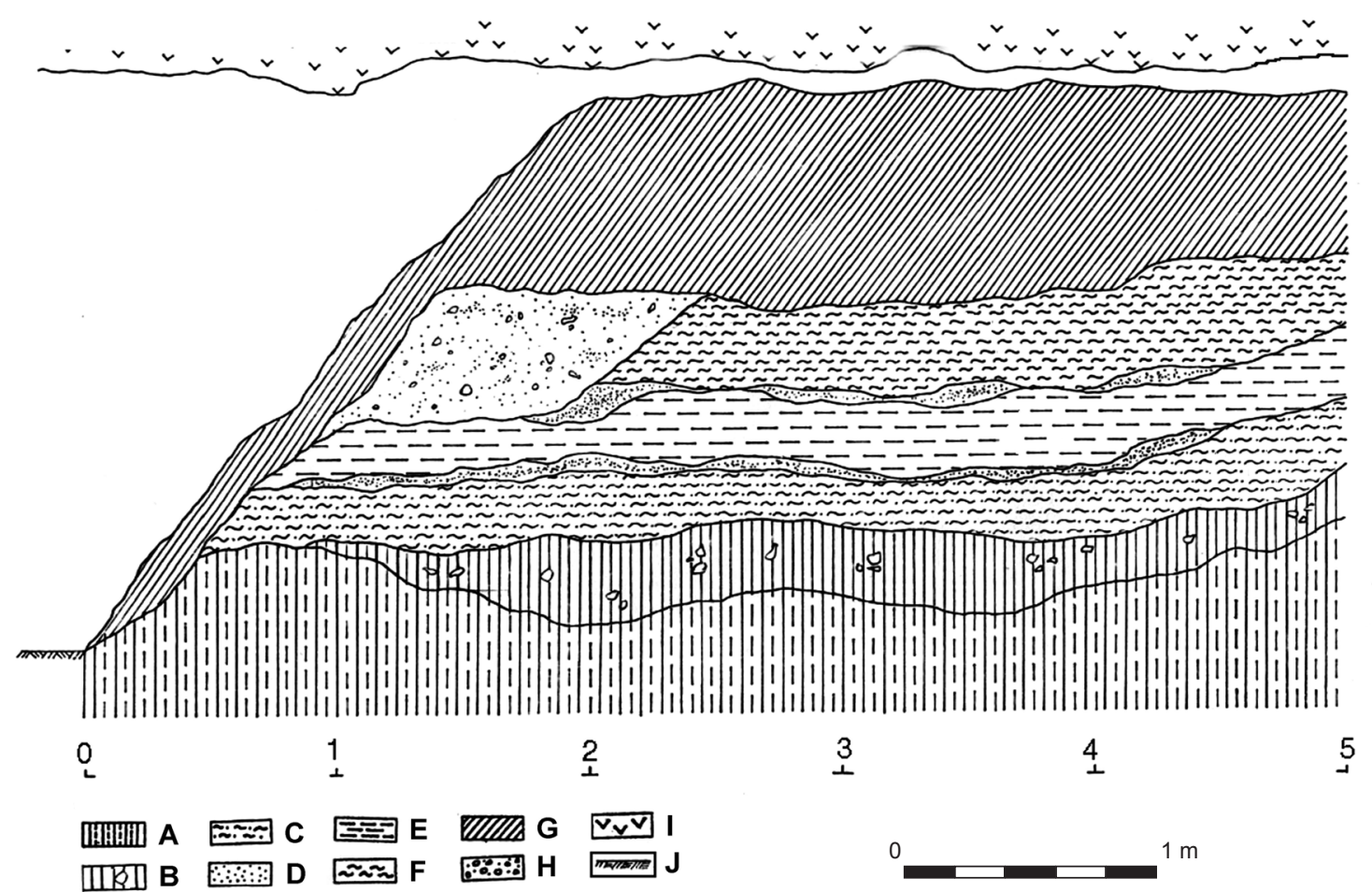

Figure 6. A cross-section of the Verteba Cave stratification, based on site \#7. The definitions of each horizon are given in the text. A, Horizon 1, bentonite clay over gypsum matrix; B, Horizon 2, loam with gravel, $\sim 30 \mathrm{~cm}$ (anthropogenic in origin, likely function is to even the cave floor); C, Horizon 3, first cultural layer, $\sim 22 \mathrm{~cm}$ (carbonate clay mixed with charcoal and burnt gypsum); D, Horizon 4, $\sim 10 \mathrm{~cm}$ (archaeologically sterile yellow clay, also found in uneven patches between E and F); E, Horizon 5, second cultural layer, $\sim 35-40 \mathrm{~cm}$ (burnt gypsum, charcoal with fragments of burnt wood); F, Horizon 6 , third cultural layer, $\sim 60 \mathrm{~cm}$ (ashy clay mixed with gravel, burnt lime and charcoal) ; G, Horizon 7, alluvial soil (chernozem), $\sim 80-100 \mathrm{~cm}$, archaeologically sterile; H, overfill; I, gypsum; J, current floor level.

Figure 7. Verteba Cave layout, indicating locations from where samples were taken for radiocarbon and ancient DNA analyses. Numbering corresponds to Table 1.

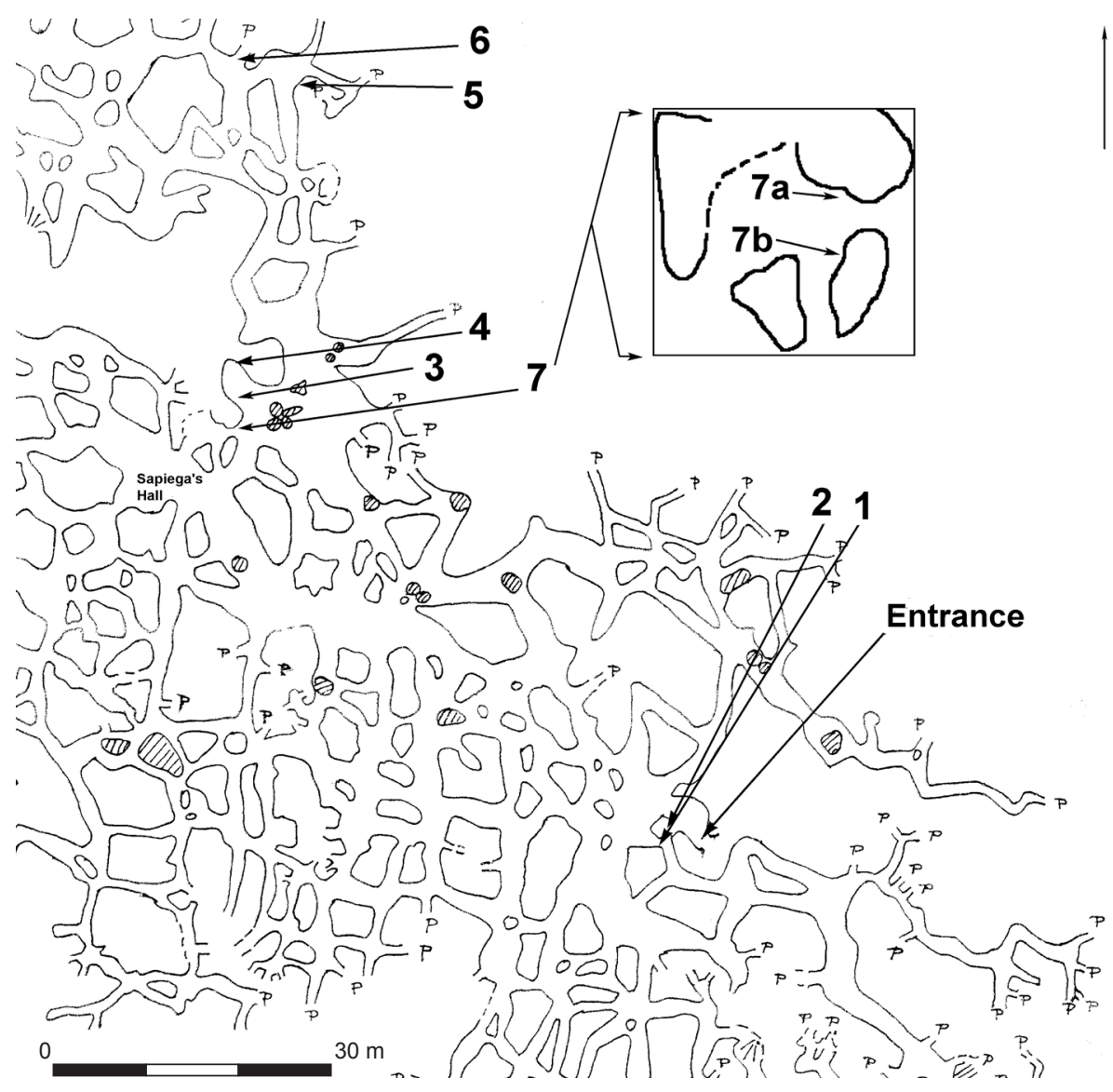


Table 1. Radiocarbon dates of human and animal bone, coal and matrix samples from Verteba Cave. Position numbers correspond to Figure 7. Calibrated dates were obtained using OxCal 4.1.3 online calibration software (Bronk Ramsey 2009) with IntCal 04 atmospheric curve (Reimer et al. 2004). MtDNA haplogroups are indicated on samples for which that information is available.

\begin{tabular}{|c|c|c|c|c|c|}
\hline Material (position) & Sample code & $\begin{array}{c}\text { Uncalibrated date, } \\
\text { BP }\end{array}$ & $\begin{array}{c}\text { Calibrated date, } \\
\text { cal } \mathrm{BC}(95.4 \%, 2 \partial)\end{array}$ & $\begin{array}{c}\text { Pottery typology } \\
\text { or specimen } \\
\text { description }\end{array}$ & $\begin{array}{l}\text { Mitochondrial DNA } \\
\text { haplogroup }\end{array}$ \\
\hline Human bone $^{1}(1)$ & Ki-13388 & $4550 \pm 90$ & $3619-2936$ & Mandible & $\mathrm{H}$ \\
\hline Matrix (2) & Ki-13070 & $4560 \pm 80$ & $3620-3021$ & - & \\
\hline Human bone $^{1}(2)$ & Ki-14947 & $4580 \pm 50$ & $3511-3099$ & Radius & Pre-HV \\
\hline Charcoal (2) & $\mathrm{Ki}-13071$ & $4600 \pm 80$ & $3631-3036$ & - & \\
\hline Painted pottery (2) & Ki-13069 & $4730 \pm 90$ & $3703-3341$ & KO type & \\
\hline Painted pottery (2) & Ki-13068 & $4810 \pm 100$ & $3795-3365$ & KO type & \\
\hline Human bone (3) & Ki-16155 & $4520 \pm 70$ & $3497-3294$ & Sacrum axis & \\
\hline Human bone $^{1}(4)$ & Ki-12694 & $4180 \pm 90$ & $3006-2488$ & Middle rib & $\mathrm{J}$ (root) \\
\hline Animal bone (5) & Ki-13067 & $4340 \pm 100$ & $3349-2679$ & Swine & \\
\hline Animal bone (5) & $\mathrm{Ki}-13065$ & $4420 \pm 100$ & $3364-2888$ & Swine & \\
\hline Matrix and charcoal (5) & Ki-13064 & $4570 \pm 110$ & $3631-2934$ & - & \\
\hline Pottery $(5)$ & Ki-13066 & $4720 \pm 110$ & $3711-3105$ & Possibly KO type & \\
\hline Human bone ${ }^{1}(5)$ & Ki-15051 & $4720 \pm 70$ & $3638-3370$ & Middle rib & $\mathrm{T} 4$ \\
\hline $\begin{array}{l}\text { Pottery, broken in two } \\
\text { pieces (6) }\end{array}$ & $\begin{array}{c}\mathrm{Ki}-14683 \\
\mathrm{Ki}-14683 \mathrm{a}\end{array}$ & $\begin{array}{l}4720 \pm 90 \\
4910 \pm 140\end{array}$ & $\begin{array}{l}3761-3367 \\
3984-3371\end{array}$ & SHY type & \\
\hline Human bone ${ }^{1}(6)$ & Ki-14308 & $4910 \pm 400$ & $4652-2674$ & Rib fragment & No DNA \\
\hline Animal bone (7) & Ki-16153 & $4165 \pm 70$ & $2902-2573$ & Undetermined & \\
\hline Human bone $^{1}(7 a)$ & Ki-16152 & $4215 \pm 70$ & $3006-2578$ & Skull fragment & $\mathrm{HV} / \mathrm{V}$ \\
\hline Human bone (7) & $\mathrm{Ki}-15037$ & $4450 \pm 60$ & $3350-2920$ & Undetermined & \\
\hline Animal bone (7) & Ki-15763 & $4530 \pm 60$ & $3380-3020$ & Undetermined & \\
\hline Human bone (7) & Ki-16156 & $4600 \pm 80$ & $3631-3036$ & Rib & \\
\hline Pottery (7) & Ki-14682 & $4630 \pm 130$ & $3655-2943$ & N/A & \\
\hline Pottery (7) & Ki-15762 & $4670 \pm 90$ & $3380-3020$ & N/A & \\
\hline Human bone $^{1}(7 b)$ & Ki-14307 & $4680 \pm 60$ & $3634-3358$ & Phalange & $\mathrm{H}$ \\
\hline Human bone (7) & $\mathrm{Ki}-15039$ & $4680 \pm 40$ & $3628-3366$ & Long bone fragment & \\
\hline Human bone (7) & Ki-15038 & $4720 \pm 40$ & $3635-3374$ & Rib & \\
\hline Pottery (7) & $\mathrm{Ki}-15756$ & $4730 \pm 80$ & $3655-3359$ & N/A & \\
\hline Pottery (7) & Ki-15760 & $4760 \pm 80$ & $3694-3367$ & BII & \\
\hline Pottery (7) & Ki-15758 & $4780 \pm 80$ & $3710-3360$ & Possibly BII & \\
\hline Human bone (7) & $\mathrm{Ki}-15036$ & $4810 \pm 60$ & $3710-3490$ & Undetermined & \\
\hline Pottery (7) & Ki-15757 & $4820 \pm 90$ & $3790-3370$ & Possibly CI & \\
\hline Pottery (7) & Ki-15761 & $4840 \pm 90$ & $3800-3350$ & BII & \\
\hline Pottery (7) & Ki-15759 & $4890 \pm 90$ & $3950-3500$ & N/A & \\
\hline Human bone (7) & n.d. & n.d. & n.d. & Vertebrae & $\mathrm{HV} / \mathrm{V}$ \\
\hline
\end{tabular}

${ }^{1}$ Samples used in the DNA analysis.

followed during specimen retrieval to minimise the chance of sample contamination with modern DNA. DNA extraction and processing were conducted following the standards for working with ancient DNA (Cooper, Poinar 2000) as close as possible. All ancient sample manipulation, including the retrieval of samples from the matrix, was performed by a single person (AGN) to minimise the chances of specimen contamination with modern DNA. The control region of mtDNA was amplified in four overlapping segments, using the Polymerase Chain Reaction (PCR) technique. Amplification products were analysed by direct sequencing and cloning. Three segments of the coding region of mtDNA containing diagnostic polymorphisms for general mtDNA lineage assignment were amplified and analysed using the Restriction Fragment Length Polymorphism (RFLP) method. One of the four control region segments as well as one of the three coding region segments contained a researcher-specific polymorphism, to control for the most likely source of modern DNA contamination.

\section{Results}

\subsection{Verteba Cave chronology}

Radiocarbon analysis of pottery, human and animal bone, associated charcoal and matrix, as well as pottery typology 
analysis, produced a comprehensive chronological sequence of cave occupation by local TC groups. Table 1 lists the radiocarbon dates for the artefacts found in the archaeological context and the typology analysis of the pottery. The artefact selection in this report spans the timeframe from $4910 \pm 140$ $\mathrm{BP}$ to $4165 \pm 70 \mathrm{BP}$, extending previously reported site occupation by TC groups (Kadrow et al. 2003) by over 100 years.

Pottery identified as belonging to the SHY style dated within the 4910-4760 BP range (Table 1). At least two human osteological specimens are within that range (4910-4810 $\mathrm{BP})$. The radiocarbon dating of the former produced a large error but was found in the context of the SHY pottery. The pottery sherds in the 4730-4630 BP range are likely from the KO phase. Most human bone samples belong to this age diapason as well. The KA phase has no representative pottery in the sample presented in this report. The presence of TCKA pottery elsewhere in the cave and aboveground and the absence of non-TC-KA time period artefacts otherwise (M. Sokhatsky, unpublished) suggests the bone samples dated to 4215-4165 BP belong to the KA phase of TC.

The existence of an archeologically sterile layer between cultural layers 1 and 2 as well as patches of sterile clay between layers 2 and 3 (Figure 6) indicates breaks in cave usage. The duration of the uniformly continuous break between layers 1 and 2 can be estimated from the thickness of each horizon, correlated with previous (Kadrow et al. 2003) and current radiocarbon data points, and also assuming that alluvial accumulations were continuously uniform. The thickness of the first cultural layer (Horizon 3, Figure 6) is about $22 \mathrm{~cm}$ and corresponds to cave exploitation by the SHY group for a period of about 195 years, starting around $3745 \mathrm{BC}$ and ending around 3550 BC (Kadrow et al. 2003). The layer can be estimated to have formed at a density of $0.11 \mathrm{~cm} /$ year $(22 \mathrm{~cm}$ divided by 195 years). KO and KA groups utilized the cave for about 803 years from 3550-2747 BC. The youngest date (calculated as the average of the limits of the second sigma for the youngest human bone, Table 1) from the cave occurs right at the end of the KA phase. Therefore the thickness of the second and third cultural layers $(100 \mathrm{~cm}$, Figure $6 \mathrm{~F})$ divided by 803 years equal $0.12 \mathrm{~cm} /$ year. The average of the two values is $0.115 \mathrm{~cm} /$ year. Thus the $10 \mathrm{~cm}$ of the sterile horizon between the first and second cultural layers deposited at $0.115 \mathrm{~cm}$ per year could have formed in about 87 years.

Radiocarbon dates from site \#7 indicate that site activity peeks around $3500 \mathrm{BC}$, though the site was visited at earlier
Figure 8. Plot of calibrated radiocarbon dates obtained from site \#7 (see Table 1). Calibrated dates were obtained using $\mathrm{OxCal}$ 4.1.3 online calibration software (Bronk Ramsey 2009) with IntCal 04 atmospheric curve (Reimer et al. 2004).

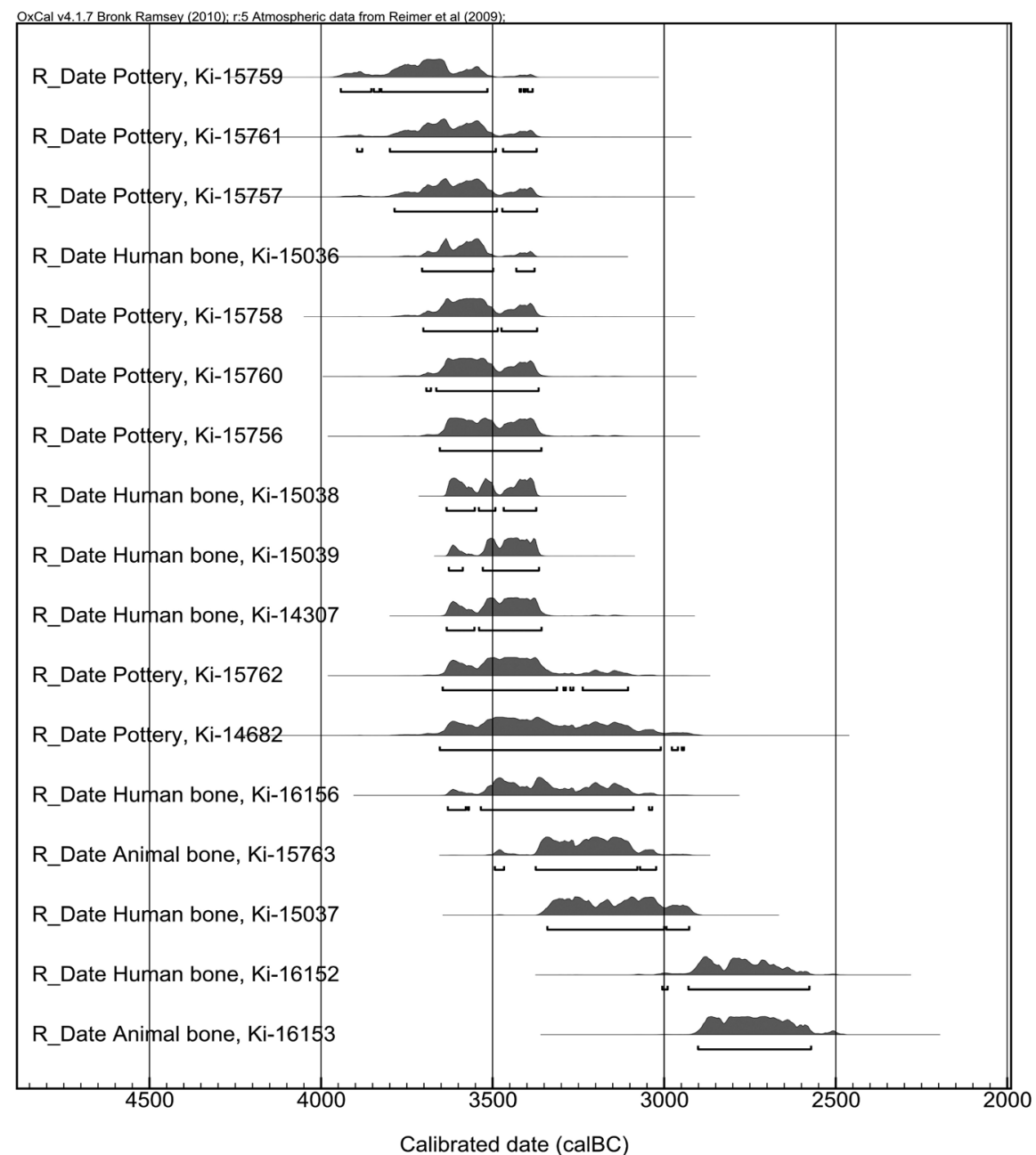


and later times, particularly near the end of the TC reign in the area, around $2700 \mathrm{BC}$ (Figure 8). In total the site was utilised for nearly 800 years and apparently by all three local TC groups. The $3500 \mathrm{BC}$ period corresponds to a transition from SHY to KO (Kadrow et al. 2003). In local prehistory this period is also associated with a shift in the Trypillian populations of Northern Dnistér, from a stable growth towards a decline (T. Tkachuk, personal communication). Based on carbon dating, cave geology and pottery typology analyses, the near 90-year break in cave usage between the first and second cultural layer likely falls around the time of this transition.

\subsection{Ancient mtDNA analysis}

Of the seven samples from which ancient mtDNA were successfully retrieved five belong to the pre-HV branch of the $\mathrm{R}$ lineage of mtDNA phylogenetic tree (Torroni et al. 2006), and include one pre-HV specimen, two $\mathrm{HV} / \mathrm{V}$ and two $\mathrm{H}$ specimens. The two remaining specimens belong to the JT cluster of the mtDNA phylogenetic tree (Table 1). The chronologically oldest sample in the set belongs to the T4 haplogroup and the youngest sample to the J haplogroup (root sequence).

\section{Discussion}

There are no TC sites similar to Verteba anywhere in Ukraine - or at least none have been discovered so far. Finds of preCII TC human remains is a rarity, as it is likely that early Trypillians disposed of their dead in an archeologically untraceable manner. On the other hand finds of singular bones within TC settlements from different chronological periods (Videiko 2004) could be linked to some form of ritual involving the dead, which may not have been directly associated with burial practice. In fact the variety of material artefacts found in the cave, such as bovid head-shaped plaques, stone mills and loom weights, may have had to do with spirit communication rather than funerary rite. It is noteworthy that the practice of bone deposition in the cave does not seem to change from the SHY (BII-CI) to KO and KA (CII) phases, suggesting a long-lasting ritual that might have transcended cultural changes associated with a change from one local phase to another.

Material culture evidence suggests that Trypillian inhabitants of the Verteba Cave area had extensive relations with such contemporary central European cultures as TiszaPolgár and Baden (Tkachuk 2000), likely prompted by copper mining around the Verteba Cave area (Sokhatskij et al. 2000). Caves with human remains attributed to the latter two cultures are known in Slovakia (Soják, Horváthová 2008), implying and eastward-bound flow of ritual practices in Eneolithic Europe and the likely origin of the Verteba tradition.

The overall mtDNA haplotype composition of TC specimens from Verteba suggests that the local TC population around Verteba was fairly heterogeneous. However, when considering the wide chronological age of the specimens (Table 1) the haplogroup diversity may also indicate population flow within that time frame. If the samples are organised in chronological sequence they can be matched to three distinct local archaeological groups. It appears that the oldest sample (T4 haplogroup) likely belongs to the SHY group, the youngest sample (J haplogroup) to the KA group, and the rest of the TC samples (pre-HV, $\mathrm{H}^{*}, \mathrm{HV} / \mathrm{V}$ ) to the $\mathrm{KO}$ group.

The pre-HV and HV/V haplogroups are at the base of one of the three mtDNA haplogroup branches that gave rise to most modern European mtDNA lineages (Torroni et al. 2006). A pre-HV/HV sample was uncovered in an analysis of the 23-KBP Cro-Magnon remains from Southern Italy (Caramelli et al. 2003). Thus there is evidence of pre-HV/HV being of European Palaeolithic roots. The $\mathrm{H}$ clade to which two of the seven Verteba specimens belonged likely arrived in Europe in the Pleistocene (Richards 2003) and survived locally through the last Ice Age (Nikitin et al. 2009).

The $\mathrm{J}$ lineage of the JT cluster of mtDNA is considered a genetic hallmark of the Neolithic agricultural advancement out of the Near East (Richards et al. 1998). Therefore the $\mathrm{J}$ remains found at Verteba can be linked to the carriers of the Neolithic farming expansion. The phylogenetic age of the $\mathrm{T}$ lineage found in $\mathrm{TC}$ is difficult to assess although the coalescence estimate for the root sequence variants of $\mathrm{J}$, and subclades of T, suggests its arrival in Europe to have been a peri-Neolithic event (Richards 2003).

The T sample from TC belongs to the T4 branch of the phylogenetic tree for $\mathrm{T}$, while the Neolithic populations west of the Carpathian Mountains predominantly harboured a different T sublineage (Haak et al. 2005, Sampietro et al. 2007). This suggests a different origin of $T$ lineages in the east Carpathian region compared with the rest of Europe. It has been suggested that the spread of Neolithic technologies in Ukraine could have proceeded along two possible routes, one from Central Europe, carried by the LBK complex around the northern slope of the Carpathians, and an earlier one from the south associated with the Bug-Dnistér culture (Potekhina, Telegin 1995). Thus prehistoric south Ukrainan populations of the North Pontic region could have harboured distinct genetic lineages, possibly including lineages of the $\mathrm{T}$ haplogroup, which could have ended up in TC through population exchanges during the Neolithic. The MesolithicNeolithic DNA from the North Pontic region could help evaluate this possibility.

To put the mtDNA results from Verteba into a more comprehensive context of the genetics of Neolithic Europe, the pertinent Y chromosome evidence needs to be addressed. Based on the Y haplogroup frequencies distribution analysis by Semino et al. (2000), King and Underhill (2002) proposed a correlation between the western European-specific Y haplogroup Eu9 (M172) and the appearance of painted ceramics during the European Neolithic. They hypothesised that it was the Eu9-carrying males who brought these new 
cultural attributes into Europe from the near East. They also noted that their prediction did not correlate well with the finding of painted ceramics and figurines in Ukraine because of the low frequency of Eu9 found there (King, Underhill 2002). The authors explained this lack of geneticcultural correlation by the Mesolithic beginning of the Ukrainian Neolithic pottery. However the painted ceramics, anthropomorphic and zoomorphic figurines, as well as other elements of ceramic usage that are abundantly found in association with TC sites (Kandyba 1937, Zbenovich 1996, Videiko 2004), suggest a strong Near Eastern influence on TC. The absence of these ceramic elements in the Ukrainian Mesolithic-Neolithic transition sites argues against the autochthonous Mesolithic beginnings of the Neolithic ceramic industries of Trypillia.

A cultural connection with the Near East could be further evidenced from the two bovid head shaped bone plates found at Veteba. One of these plates was found by V. Demetrikevich at the turn of the $20^{\text {th }}$ century (Figure $2 \mathrm{~A}$ ), and another one by M. Sokhatsky in the 1990s (Figure 2B). One of these plates has a female figurine etched on its surface (Figure 2A), while the other (Figure 2B) contains no image. The horns have an obvious "lyre" shape and are made to exaggerate that feature. Of the domestic and wild cattle of the TC times, only the wild aurochs had lyre-shaped horns (van Vuure 2005). Aurochs depicted on ritual objects, including bas-reliefs and stone carvings, are characteristic to Near Eastern rituals, going to the Pre-Pottery Neolithic (Goring-Morris, Horwitz 2007). These finds can therefore be viewed as a ritual connection, in addition to pottery-making, between TC and the Near East.

To sum up the genetic evidence: the maternal genetic lineages from Verteba are predominantly pre-Neolithic, with a near $30 \%$ admixture of peri-Neolithic haplogroups. This haplogroup ratio is consistent with previous estimates of Neolithic genetic contributions to the European gene pool (Richards et al. 1996). However if J lineages in TC population around Verteba were, indeed, absent prior to the very late phase of TC existence, then the J lineage could have arrived after the establishment of agriculture and associated pottery technologies in the area. Thus based on the modern (Y chromosome) and ancient (mtDNA from Verteba) genetic evidence, the adoption of farming by the TC groups in western Ukraine can be viewed as an acculturation event by indigenous local groups rather than a population migration of the carriers of agricultural technology. Additional TC DNA data is necessary to clarify this issue.

\section{Conclusion}

Verteba is a unique site of pre-historic human activity, which was almost continuously utilised by local Trypillian groups for nearly a millennium. The site provides an unprecedented insight into the ritual practices of Neolithic people in eastern Europe. Unlike most TC archaeological sites Verteba contains superbly preserved biological remains which can be examined in the context of material culture artefacts, aiding in a comprehensive understanding of the site's legacy. The radiocarbon chronology presented in this report makes Verteba the most extensively dated TC site, and the aDNA information obtained makes Verteba the first $\mathrm{TC}$ site to provide insight into the genetic history of the TC inhabitants.

\section{Acknowledgments}

The authors would like to thank O. Dudar and M. Boyko for their excellent technical assistance with the excavations at Verteba Cave, Dr. T. Tkachuk for helpful discussions and suggestions, and V. Skrypkin for technical assistance with radiocarbon analysis. This work was supported in part by a Research Seed Grant from the Michigan Space Grant Consortium and by internal research funds from GVSU.

\section{References}

BELLWOOD, P. 2005: First farmers: The origins of agricultural societies. Blackwell, Malden, MA.

BRONK RAMSEY, C. 2009: Bayesian analysis of radiocarbon dates. Radiocarbon 51, 337-60.

CARAMELLI, D., LALUEZA-FOX, C., VERNESI, C., LARI, M., CASOLI, A., MALLEGNI, F., CHIARELLI, B., DUPANLOUP, I., BERTRAPETIT, J., BARBUJANI, G., BERTORELLE, G. 2003: Evidence for a genetic discontinuity between Neandertals and 24,000-year-old anatomically modern Europeans. Proceedings of the National Academy of Sciences USA 100, 6593-6597.

CHILDE, V. G. 1923: Schipenitz: A late Neolithic station with painted pottery in Bukowina. The Journal of the Royal Anthropological Institute of Great Britain and Ireland 53, 263-288.

COOPER, A., POINAR, H. 2000: Ancient DNA: Do it right or not at all. Science 289, 1139.

DERGATSCHOV, V. 1991: Bestattungskomplexe der späten TripoljeKultur. Materialien zur Allgemeinen und Vergleichenden Archäologie. Bd 45. P. von Zabern, Mainz am Rhein.

DERGATSCHOV, V. A., MANZURA, I. V. 1991: Pogrebal'nye kompleksy pozdnego Trypolya. Shytnytsa, Kishinew.

GORING-MORRIS, N., HORWITZ, L K. 2007: Funerals and feasts during the Pre-Pottery Neolithic B of the Near East. Antiquity 81, $902-919$.

HAAK, W., FORSTER, P., BRAMANTI, B., MATSUMURA, S., BRANDT, G., TÄNZER, M., VILLEMS, R., RENFREW, C., GRONENBORN, D., ALT, K. W., BURGER, J. 2005: Ancient DNA from the first European farmers in 7500-year-old Neolithic sites. Science 310, 1016-1018.

KADROW, S., SOKHACKIY, M., TKACHUK, T., TRELA, E. 2003: Sprawozdanie ze studiów I wyniki analiz materiałów zabytkowych kultury trypolskiej z Bilcza Złotego znajdujacych się w zbiorach museum archeologicznego w Krakowie. Materiaty Archeologiczne XXXIV, 53-143.

KANDYBA, O. 1937: Schipenitz. Kunstund Gerfte elnes neolithishen Dorfes. Leipzig-Wien.

KHVOIKA, V. V. 1901: Kamennyj vek Srednego Podneprovya. Trudy XI arkheologicheskogo s'ezda 2, 789-812.

KING, R., UNDERHILL, P. A. 2002: Congruent distribution of Neolithic painted pottery and ceramic figurines with Y-chromosome lineages. Antiquity 76, 707-714.

KOTOVA, N. S. 2003: Neolithization of Ukraine. British Archeological Reports, Oxford.

KRUSHELNYTSKA, L., BANDRIVSKY, M. 1998: Arkheologychny rozkopky A. Kirkora I G. Osovs'kogo na Ternopil'schyni 70-90 rr. XIX st. Materyaly I doslidzhennya z arkheologii Prykarpattya I Volyny 7, 74. 
NIKITIN, A. G., KOCHKIN, I. T., JUNE, C. M., WILLIS, C. M., McBAIN, I., VIDEIKO, M. Y. 2009: Mitochondrial DNA sequence variation in the Boyko, Hutsul, and Lemko populations of the Carpathian highlands. Human Biology 81, 43-58.

POTEKHINA, I., TELEGIN, D. 1995: On the dating of the Ukrainian Mesolithic-Neolithic transition. Current Anthropology 36, 823-826.

REIMER, P. J., BAILLIE, M. G. L., BARD, E., BAYLISS, A., BECK, J. W. BERTRAND, C. J. H. et al. 2004: IntCal04 terrestrial radiocarbon age calibration, 0-26 cal kyr BP. Radiocarbon 46, 1029-1058.

RICHARDS, M. 2003: The Neolithic invasion of Europe. Annual Review of Anthropology 32, 135-62.

RICHARDS, M., CÔRTE-REAL, H., FORSTER, P., MACAULAY, V., WILKINSON- HERBOTS, H., DEMAINE, A., PAPIHA, S., HEDGES, R., BANDELT, H.-J., SYKES, B. 1996: Paleolithic and Neolithic lineages in the European mitochondrial gene pool. American Journal of Human Genetics 59, 185-203.

RICHARDS, M. B., MACAULAY, V. A., BANDELT, H.-J., SYKES, B. C. 1998: Phylogeography of mitochondrial DNA in western Europe. Annals of Human Genetics 62, 241-260.

ROOK, E., TRELA, E. 2001: Stanowiska kultury trypolskiej w Bilczu Zlotym w dawmym powiecie Borszcow, w swietlie zbiorow krakowskich. In: E. Rook \& E. Trela, E.: Z archeologij Ukrainy i Jury Ojcowskiej. Ojcow, 183-206.

SAMPIETRO, M. L., LAO, O., CARAMELLI, D., LARI, M., POU, R., MARTI, M., BERTRANPETIT, J., LALUEZA-FOX, C. 2007 Palaeogenetic evidence supports a dual model of Neolithic spreading into
Europe. Proceedings of the Royal Society B: Biological Sciences 274, 2161-2167.

SEMINO, O., PASSARINO, G., OEFNER, P. J. et al. 2000: The genetic legacy of Paleolithic Homo sapiens sapiens in extant Europeans: A Y chromosome perspective. Science 290, 1155-1159.

SOJÁK, M., HORVÁTHOVÁ, E.: Neolitické a eneolitické osídlenie Puklinovej jaskyne na Dreveníku pri Žehre. Otázky Neolitu a Eneolitu našich zemí 27, Vranov Nad Dyjí, Slovakia, 2008.

SOKHATSKIJ, M., KLOCHKO, V., MANICHEV, V., KVASNISTA, V., KOZAK, S., DEMCHENKO, L. 2000: Issues concerning Tripolye metallurgy and the virgin copper of Volhynia. Baltic-Pontic Studies 9, $168-186$.

STOJANOWSKI, K. 1948: Antropologia Prehistoryczna Polski. Polska Akademia Umiejętności, Prace I Materiały Antropologiczne, Tom II, NR 1. Publikacje Komitetu Wydawnictw Śląskich, Krakow, 62 p.

TKACHUK, T. 2000: The Koshylivtsy Group as a synthesis of the Tripolye and Polgar Traditions. Baltic-Pontic Studies 9, 69-85.

TORRONI, A., ACHILLI, A., MACAULAY, V., RICHARDS, M., BANDELT, H.-J. 2006: Harvesting the fruit of the human mtDNA tree. Trends in Genetics 22, 339-345.

VIDEIKO, M. Y (ed.). 2004: Encyclopedia of Trypillian Civilization. Ukrpoligraphmedia, Kyiv.

van VUURE, C. 2005: Retracing the Aurochs: History, Morphology and Ecology of an extinct Wild Ox. Pensoft, Sofia-Moscow, $424 \mathrm{p}$.

ZBENOVICH, V. G. 1996: The Tripolye culture: Centenary of research. Journal of World Pre-History 10, 199-241. 